\title{
IAMJ
}

INTERNATIONAL

AYURVEDIC

MEDICAL JOURNAL

doi) $\bigcirc$

Review Article

ISSN: 2320-5091

Impact Factor: 6.719

\section{MUSCULAR DYSTROPHY IN CHILDREN AND ITS AYURVEDIC APPROACH}

\author{
Sameer Muratkar $^{1}$, Singh Sudha ${ }^{2}$, Deodas M.S. ${ }^{3}$
}

${ }^{1}$ PG Scholar, ${ }^{2}$ Associate Professor, ${ }^{3}$ Professor,

Department of Kaumarbhritya, PDEA'S College of Ayurveda \& Research Centre, Nigdi, Pune-44; Maharashtra, India

Corresponding Author: sameermuratkar@gmail.com

https://doi.org/10.46607/iamj13p5052021

(Published online: July 2021)

Open Access

(C) International Ayurvedic Medical Journal, India 2021

Article Received: 24/06/2021 - Peer Reviewed: 22/07/2021 - Accepted for Publication: 26/07/2021

\section{Check for updates}

\begin{abstract}
Muscular dystrophy refers to a group of disorders that involve a progressive loss of muscle mass due to failure to regenerate muscle fibres with a genetic cause. Then it results in progressive muscle weakness leads to loss of strength, muscle atrophy, tonicity, gait, and walking problems. Yet corticosteroids are the only pharmacological palliative management available for DMD in modern medicine having long term side effects. In Ayurveda, it is a kind of Aadhibala Pravrutta Vyadhi, caused due to Beeja Bhaga Avayava Dusti. Since dystrophies are inevitably progressive disease leads to Mamsa kshaya. With ayurvedic principles, the progression of the disease can be postponed and improve the quality of life by adopting Santarpana line of treatment.
\end{abstract}

Keywords: Muscular dystrophy, Mamsa Kshaya, Aadhibhala Pravrutta, Santarpana.

\section{INTRODUCTION}

The Greek term dystrophy ('dys' meaning abstract and 'trophy' meaning nourishment) implies aberrant growth or nutrition of muscle fibres ${ }^{(1)}$. Muscular dystrophy refers to a group of disorders that involve a progressive loss of muscle mass which further leads to loss of strength.
Muscular dystrophy is caused by genetic mutations that interfere with the production of muscle proteins that are needed to build and maintain healthy muscles. The muscle fails to regenerate resulting in progressive weakness and confining to a wheelchair, which eventually leads to death. 
Muscular dystrophies are diseases of muscle membrane or supporting proteins that are generally characterized by pathological evidence of ongoing muscle degeneration and regeneration ${ }^{(2)}$.

Dystrophies have been classified according to their mode of inheritance into X- linked, autosomal and mitochondrial inheritance.

Following are the types of muscular dystrophy-(3)
1) Duchenne muscular dystrophy.

2) Becker muscular dystrophy.

3) Scapuloperoneal or scapulohumeral muscular dystrophy.

4) Myotonic muscular dystrophy.

5) Limb-girdle muscular dystrophy.

6) Facioscapulohumeral muscular dystrophy.

7) Congenital muscular dystrophy.

Table 1: (Types of muscular dystrophies and their inheritance)

\begin{tabular}{|c|l|l|}
\hline Sr.no & Type of muscular dystrophy & Genetic inheritance \\
\hline 1$)$ & Duchenne muscular dystrophy & X- linked recessive \\
\hline 2$)$ & Becker muscular dystrophy & X- linked recessive \\
\hline 3$)$ & Scapulohumeral muscular dystrophy & Autosomal dominant \\
\hline 4$)$ & Myotonic muscular dystrophy & Autosomal dominant \\
\hline 5$)$ & Limb-girdle muscular dystrophy & Autosomal dominant / Autosomal recessive \\
\hline 6$)$ & Facioscapulohumeral muscular dystrophy & Autosomal dominant \\
\hline 7$)$ & Congenital muscular dystrophy & Autosomal recessive \\
\hline
\end{tabular}

Muscular dystrophies have four obligatory criteria that distinguish them from other neuromuscular disorders, namely- ${ }^{(4)}$

- They are primary myopathies.

- They have a genetic basis.

- They have progressive effortless courses.

- They have degeneration and death of muscle fibres at some stage manifest as an increase in serum creatine phosphokinase level in blood investigation.

A lack of a protein called dystrophin is the main cause of muscular dystrophy.

The most common muscular dystrophy is Duchenne muscular dystrophy (DMD) in children.

\section{Duchenne Muscular Dystrophy}

This is the most common type of progressive muscular dystrophies, transmitted in an X-linked recessive manner affecting only males and carried by females. DMD is characterized by progressive symmetrical muscle weakness that affects proximal muscles more than distal, often accompanied by calf muscle pseudo-hypertrophy. It manifests before the fifth year of life and generally proves fatal in the second decade.
The incidence rate of Duchenne muscular dystrophy is 1 in 3500 live male births ${ }^{(5)}$. It accounts for approximately $60 \%$ of all muscular dystrophy cases. The prevalence of DMD is three times higher than that of BMD. After birth, the Sequencing of the presentation starts with mildly delayed milestones during the toddler period, often toe-walking, difficulty to raise from the floor and frequent falls. By the age of 5 years, a marked disparity between physical ability and surrounding peers occurs. During 2nd decade of life; respiratory, cardiac \& orthopaedic involvement takes place and without any medical intervention, leads to a cost of life expectancy (at the age of 18 to 20 years).

\section{Hypothesis about DMD pathogenesis}

Pathologic changes include various stages of necrosis of muscle increase in fat and endomysial connective tissue. There are signs of regeneration that eventually disappear.

Muscle lesions are secondary to microinfarcts as a result of disordered circulation. Muscle lesions are due to neuronal dysfunction, Genetic defect in muscle surface membranes. Defective DNA repair mechanism as a result of insult from some DNA-damaging agent, e.g. ionizing radiation or similar injury. 


\section{Manifestation-}

- The earliest manifestations include difficulty in standing or walking and climbing stairs. Frequent fall while running /brisk walking by the age of 3 or more.

- A most salient feature in muscular dystrophy is adopting a prone position before standing persisting beyond 3 years.

- Gower sign - the climbing up the legs sign. Gowers sign as the characteristic patterns observed in patients with Duchenne muscular dystrophy wherein, they 'climb up' their thighs with the aid of their hands to overcome the weakness of their pelvic and proximal lower limb muscles.

- Early hypertrophy of calf muscles is also a useful sign. ${ }^{(7)}$

- waddling gait (Trendelenburg gait) may be noticed ${ }^{(8)}$. Here waddle means to walk with short steps and a clumsy swaying motion. Due to weakness in the gluteus medius muscle, the hip on the side of the swinging leg drops with each step (referred to as the Trendelenburg sign). The gait appears waddling.

- Toddlers might assume a lordotic posture when standing to compensate for gluteal weakness.

- The patient may find it difficult to comb his hair or raise his hands above the head ${ }^{(9)}$.

- Pain and stiffness in the muscles and frequent falls.

- Delayed speech development.

- The muscles of the heart can be weakened leading to cardiac problems.

- Difficulty in swallowing.

- Cardiomyopathy and arrhythmias are the major cardiac manifestations in $\mathrm{DMD}^{(10)}$.

\section{DIFFERENTIAL -}

Many other genetic diseases affect the muscles, the nerves, or the neuromuscular junction. Such diseases as inflammatory myopathy, progressive muscle weakness, and cardiomyopathy (heart muscle weakness that interferes with pumping ability) may produce symptoms that are very similar to those found in some forms of muscular dystrophy), but they are caused by different genetic defects. Examples-
- Cerebral hypotonia,

- Spinal injury-induced hypotonia

- congenital demyelinating neuropathy.

- Peripheral neuropathies, including acute inflammatory demyelinating polyneuropathy (Guillain Barre syndrome)

- Disorders of the neuromuscular junction to be considered in the differential diagnosis include congenital myasthenic syndromes, transient neonatal myasthenia gravis.

\section{Diagnosis}

The clinical impression may be supported by the following investigations.

Creatine kinase: - There is an increase in serum level of creatine phosphokinase muscle/brain (CPKMB). The serum creatine kinase levels are greatly elevated (greater than 10 times) ${ }^{(11)}$.

Nerve conduction velocity (NCV) study will be normal, and electromyography (EMG) will show a myopathic pattern.

Electromyography (EMG):- A needle is placed into the muscle to measure electrical activity.

Muscle biopsy- Muscle biopsy reveals hyaline hypereosinophilic fibres scattered within the vesicles with characteristic crowding of the multinucleated nuclei in the centre, degenerative fibres, and fat infiltration.

Genetic testing

Heart monitoring

Lung monitoring

\section{Management}

Management of a child with DMD requires a multidisciplinary team. The mainstays of management are maintenance of strength and joint range of motion by exercise, physiotherapy, and avoidance of prolonged immobility.

Corticosteroids (prednisolone and deflazacort) are the only therapies proven to improve strength and prolong ambulation in children with DMD.

Most effective dose $0.75 \mathrm{mg} / \mathrm{kg} /$ day of prednisolone. Or deflazacort $0.9 \mathrm{mg} / \mathrm{kg} /$ day, maybe more effective than prednisolone ${ }^{(12)}$.

\section{Supportive management includes:}

-pulmonary and cardiac care

-Calcium homeostasis 
-appropriate immunization

-Orthopedic care

Prognosis $^{(13)}$

Virtually all subjects become bedridden by $12 \mathrm{yrs}$ of age and about $75 \%$ die before the age of 20 years, usually from cardiomyopathy or pulmonary complications.

\section{Prevention}

Detection of female carriers by serum creatine phosphokinase estimation or quantitative EMG and genetic counselling based on localization of the gene using DNA polymorphism is important.

\section{Ayurvedic concept of Muscular Dystrophies}

In the broad classification of disease, A category is known as Adibalapravritta (genetic) disease have been included, because there is no direct reference to pseudo-hypertrophic muscle dystrophy in ayurvedic classics.

According to Ayurveda, Mamsakshaya (depletion of muscle mass) may be present under the following conditions.

1. where there is Raktakshaya (depletion of blood tissue) ${ }^{(14)}\{$ Su.su. $15 / 7\}$

2. Mamsavahasrotodushti (vitiation of muscle tissue) including Raktavahadhamnidushti (vitiation of blood tissue carrying vessels)

3. Asthigatakupitavata (predominance of Vata in bone tissue)

4. Majjagatakupitavata (predominance of Vata in bone marrow)

\section{Pathogenesis}

In this disease Vriddhi (aggravation) and Kshaya (depletion) both are seen side by side, the general dictum that all Vriddhi are due to nourishing factor and hence it is followed by Kapha and all Kshayas are due to nonnourishing component and hence it is followed by Vata can be inferred ${ }^{(15)}$.

If Kapha and its Samana guna ama (undigested thing having similar properties) cause Srotorodha (obstruction in channels) can cause Vata Prakopa which in turn cause wasting or Sosha (depletion)of the region affected by it. Ayurveda visualizes 13 Agnis (digestive fire) which are responsible for digestion and metabo- lism. Each dhatu has corresponding Agni which is responsible for the metabolism of the respective Dhatu (tissue) $^{(16)}$.

Therefore, the line of treatment according to Ayurveda for the above condition must comprise of not only Brimhana (nourishing treatment) measures but also Srotoshodhaka (to relieve the obstruction of channels), Raktaprasadaka (to improve blood supply) and Dhatvagnivardhak (to increase the tissue fire) measures.

\section{Ayurveda Management-}

Santarpana Chikitsa (nourishing treatment) oral and local is the mainstream of management start with Srotoshodhak and Amapachana Ausadhi as Agnimandya is usually at Mamsa Dhatu level.

\section{Panchakarma-}

1. Rukshana - With Shastika Churna, Kolakulatthadi Churna

2. Mridu Swedana-Dhanyamla Dhara ${ }^{(17)}$

3. Snehana with Chandanbalalakshadi Taila /Balaguduchyadi Taila /Mahamash Taila /Sashtik Taila + Shalishastik Pinda Swedana may improve the action of muscle and due to its Balya \& Brimhana effects strengthen the muscles.

4. Yapanabasti

5. Tiktakshir Basti may act as Brimhana, Balya.

6. Matrabasti- with Sahachar Tailal Kshirbala Tailal Mahamash Tailal Balaashwagandhadi Taila.

\section{Oral Drugs}

1) Raktapachak Vati

2) Mamsapachak Vati

3) Srotoshodhan Deepan-Pachan: -Agnitundi Vati, Amapachak Vati.

4) Ekaldravya-Ashwagandha, Shatavari, Shalparni, Vidarikand etc. Mamsa Vardhak herbs

5) Kalpa-

Considering Kapha and Pitta Anubandha inpatient Snehana (oleation) Swedana (fomentation) should be chosen to start with Rukshana (dry herbs rubbing to reduce ama). Controlled Rukshana and Swedana are beneficial.

Considering Dhatvagni Mandya these drugs should be prescribed orally. 
Ashwagandha Avaleha

Mahatiktak Ghrita

Amritprash Ghritam

Brihatchhasaladya Ghritam

6) Rasaushadhi-Madhumalinivasant Ras

Bruhatvatachintamani Ras, Suvarnabhupati Ras etc.

\section{DISCUSSION}

DMD is the most common muscular dystrophy in India as well as in the world, caused by mutations in the dystrophin gene because of which the body is unable to synthesize the protein dystrophin required for muscle contraction. Every time the muscle contracts, muscle damage occurs which is repaired but with deficient protein resulting in the repaired muscle which is also a damaged one.

This continuous succession of damage and repair and eventually replacement of muscle with fibrofatty tissue is responsible for the clinical signs of progressive muscle wasting and the degeneration that is usually evident by 3-4 years.

So early diagnosis and early treatment are necessary to delay the progression and involvement of vital organs like a heart in DMD. Ayurvedic management can delay the progression and improve the quality of life as allopathy have only steroids and supplements.

As the ayurvedic correlation is Mamsa Kshaya, it should respond to Brimhana and Santarpana Chikitsa, but the main pathology is Mamsa Dhatvagni Mandya and Srotavarodh. So, as per Kaphanubandha and Pittanubandha Vata Dusti, the Panchkarma effect can vary.

Practically many patients with Pittanubandh get worsen with Snehana and strong Swedana as Usnatva Guna increases and causes Pitta Prakopa and worsen the gait and walking of the patients immediately.

So, Rukshana (with Kolkulatthadi Churna) followed by Mridu Swedana with Dhanyamla Dhara give better results initially. With Deepan, Pachana and Dhatwagni Vardhaka oral medications like Mamsapachak, Agnitundivati we can add Brimhana Kalpas in Niramavastha like medicated Ghrita and Rasa Kalpas after assessment of the patient. But there is a need for long term treatment along with frequent panchakarma sittings.

\section{CONCLUSION}

This disease is Yapya in nature as Beejabhagavayava Dusti is involved.

It can be concluded that ayurvedic oral medication along with Panchkarma treatment improves the quality of life, increases span and delay the progression as well as the involvement of cardiac muscles. But these kinds of diseases required long term treatment.

\section{REFERENCES}

1. Dr. Suraj Gupte, The Short Textbook Of Pediatrics, Jaypee Publication, $12^{\text {th }}$ Edition-2016, Chapter No.42, Page No.787.

2. Op Ghai, Essential Pediatrics, Dr. Vinod K Paul, CBS Publishers \& Distributors, Eighth Edition,2013, Chapter No.19, Page No.595.

3. Dr. Suraj Gupte, The Short Textbook of Pediatrics, Jaypee Publication, $12^{\text {th }}$ Edition-2016, Chapter No.42, Page No.787.

4. Dr. Suraj Gupte, The Short Textbook of Pediatrics, Jaypee Publication,12 ${ }^{\text {th }}$ Edition-2016, Chapter No.42, Page No.787.

5. Op Ghai, Essential Pediatrics, Dr. Vinod K Paul, CBS Publishers \& Distributors, Eighth Edition,2013, Chapter No.19, Page No.595.

6. Dr. Suraj Gupte, The Short Textbook Of Pediatrics, Jaypee Publication, $12^{\text {th }}$ Edition-2016, Chapter No.42, Page No.787.

7. IAP Textbook of Pediatrics, Jaypee Publication, $6^{\text {th }}$ Edition,2016, Chapter No.6.15, Page No.455.

8. Dr. Suraj Gupte, The Short Textbook Of Pediatrics, Jaypee Publication, $12^{\text {th }}$ Edition-2016, Chapter No.42, Page No.787.

9. Dr. Suraj Gupte, The Short Textbook of Pediatrics, Jaypee Publication,12 ${ }^{\text {th }}$ Edition-2016, Chapter No.42, Page No.787.

10. Op Ghai, Essential Pediatrics, Dr. Vinod K Paul, CBS Publishers \& Distributors, Eighth Edition,2013, Chapter No.19, Page No.595.

11. IAP Textbook of Pediatrics, Jaypee Publication, $6^{\text {th }}$ Edition,2016, Chapter No.6.15, Page No.456.

12. Dr. Suraj Gupte, The Short Textbook Of Pediatrics, Jaypee Publication, $12^{\text {th }}$ Edition-2016, Chapter No.42, Page No.787. 
13. Dr. Suraj Gupte, The Short Textbook Of Pediatrics, Jaypee Publication, $12^{\text {th }}$ Edition-2016, Chapter No.42, Page No.788.

14. Dr, Anant Ram Sharma, Susruta Samhita, Chaukhamba Surbharati Prakashan, Varanasi,2015, Sutra Sthana, Chapter No, $15 / 7$.

15. Prof. Jyoti Mitra, Astangsamgraha, Chowkhamba Sanskrit Series Office, Varanasi,2012, Sutrasthan, Chapter No.19.

16. Kaviraja Atrideva Gupta, Astangahrdayam, Chaukhambha Prakashan, Varanasi,2016, Sutrastanam, Chapter No.11/34.

17. Dr Dinesh K.S.; Kaumarbhritya Updated, Chaukhambha Publication,2015, New Delhi, Part B, Page 221-29.

\section{Source of Support: Nil \\ Conflict of Interest: None Declared}

How to cite this URL: Sameer Muratkar et al: Muscular Dystrophy In Children And Its Ayurvedic Approach. International Ayurvedic Medical Journal \{online\} 2021 \{cited July, 2021\} Available from: http://www.iamj.in/posts/images/upload/3037 3042.pdf 